\title{
A tradução de dois blues poems de Langston Hughes
}

Pedro Tomé

\section{O poeta}

A poesia de Langston Hughes (1902-67) foi bastante contundente no cenário literário dos EUA na primeira metade do século XX, e sua influência se faz sentir até os dias de hoje. Integrante do movimento cultural conhecido como Harlem Renaissance, ${ }^{1}$ Hughes foi pioneiro na autoafirmação literária da cultura negra, mesclando, em sua obra, uma denúncia contra a opressão racista (seu lado mais engajado) com uma celebração da cultura negra (seu lado mais musical, composto pelos poemas de blues e jazz: blues poems e jazz.poems).

Seus blues poems, que nos interessam aqui, são aqueles poemas que dialogam diretamente com o blues, emprestando desse gênero musical tanto a estruturação dos versos quanto os motivos temáticos que lhe são característicos.

No que tange à estrutura, a musicalidade de Hughes nos blues poems se manifesta sobretudo através da repetição de palavras e bordões, característica estilística fortemente arraigada no cancioneiro dos negros norte-americanos. De acordo com Élio Ferreira de Souza (2006, p. 258), em Hughes, “[a] linguagem simples, a repetição do mesmo verso no início e no interior do poema, os paralelismos, anáforas, a memória coletiva e autobiográfica indicam a herança oral da poesia negra (...)".

1 Movimento cultural das décadas de 20 e 30, sediado na comunidade negra do bairro nova-iorquino do Harlem, que teve como expoentes, além de Hughes, poetas, escritores, artistas e pensadores como W. E. B. Du Bois, Countee Cullen e James Weldon Johnson, entre outros. O Harlem Renaissance advogava um ideário político progressista, com ênfase em questões de integração racial. 
Trata-se de uma tentativa de transpor para a poesia o formato típico do blues, que assim pode ser descrito: a mesma frase é entoada duas vezes, cada uma acompanhada de um acorde musical, para depois chegar-se a uma espécie de "conclusão", na forma de uma outra frase, relacionada à primeira, e por trás da qual se ouve um terceiro acorde. Fecha-se assim o ciclo, que será em seguida reiniciado. Como ressalta James A. Emanuel, Hughes muitas vezes valeu-se dessa forma do blues, que se caracteriza pela "dicção simples, repetição e um esquema simples de rima" (1967, p. 138-139, tradução nossa). ${ }^{2}$

Para além dessa questão mais estrutural, os próprios temas abordados em sua poesia também remetem à música negra norte-americana, tais como "migração, nomadismo, cidade, melancolia, tristeza, suicídio, euforia, negativismo, trem de ferro e amor infeliz" (SOUZA, 2006, p. 21), todos motivos tradicionais do blues.

Os dois poemas que traduzimos podem ser considerados blues poems, havendo marcantes exemplos dessa influência musical. Como propostas tradutórias, buscamos: (i) manter a precisão semântica, evitando perdas de vocábulos ou grandes distorções de sentido; (ii) preservar o tom dos poemas, isto é, sua espontaneidade e coloquialidade; e (iii) emular aspectos formais, tais como rimas e aliterações, embora sem rigor excessivo.

\section{Os poemas e suas traduções}

\section{The Weary Blues ${ }^{3}$}

Droning a drowsy syncopated tune,

Rocking back and forth to a mellow croon, I heard a Negro play.

Down on Lenox Avenue the other night

By the pale dull pallor of an old gas light

He did a lazy sway . . .

He did a lazy sway . . .

2 [simple diction, repetition, and an elementary rhyme scheme]

3 O poema dá título ao primeiro volume de poesia publicado por Hughes, em 1926. A única tradução de The Weary Blues que conhecemos é a de Élio Ferreira de Souza, consignada em sua tese de doutorado (2006). Tal tradução foi realizada com a colaboração de Antônio de Sampaio e revisão de Roland Walter. 
To the tune o' those Weary Blues.

With his ebony hands on each ivory key

He made that poor piano moan with melody.

O Blues!

Swaying to and fro on his rickety stool

He played that sad raggy tune like a musical fool.

Sweet Blues!

Coming from a black man's soul.

O Blues!

In a deep song voice with a melancholy tone

I heard that Negro sing, that old piano moan-

"Ain't got nobody in all this world,

Ain't got nobody but ma self.

I's gwine to quit ma frownin'

And put ma troubles on the shelf."

Thump, thump, thump, went his foot on the floor. He played a few chords then he sang some more-

"I got the Weary Blues

And I can't be satisfied.

Got the Weary Blues

And can't be satisfied-

I ain't happy no mo'

And I wish that I had died."

And far into the night he crooned that tune.

The stars went out and so did the moon.

The singer stopped playing and went to bed

While the Weary Blues echoed through his head.

He slept like a rock or a man that's dead.

\section{O Miserável Blues}

Zumbindo zonza e sincopada melodia,

Se remexendo num cantar macio,

Ouvi um Negro tocando. 
$\mathrm{Na}$ Avenida Lenox, numa noite dessas,

Sob a palidez de uma luzinha baça,

Fez um balanço brando...

Fez um balanço brando...

Na cadência do Miserável Blues.

Em teclas de marfim, sua mão de ébano ${ }^{4}$

Fez gemer musicalmente o pobre piano.

Oh Blues!

Pra frente e pra trás em seu banquinho débil,

Tocava o triste e roto ${ }^{5}$ tema como um ébrio.

Doce Blues!

Vindo da alma de um homem negro.

Oh Blues!

Em voz profunda, carregada de pesar

Ouvi cantar o Negro e o piano lamentar -

"Num tenho ninguém nesse mundão,

Num tenho ninguém além de mim.

Eu vou largar minha carranca

E deixar ela de lado enfim."

Seu pé no chão fez "tum, tum, tum”6

Tocou acordes e cantou mais uns -

"Eu sinto o Miserável Blues,

Contente eu num consigo ficá.

Sinto o Miserável Blues,

Contente num consigo ficá.

Num sou feliz mais não,

E queria ter morrido já"

4 Aqui, o poeta faz uma interessante descrição da simbiose entre o negro e o piano: as mãos do primeiro, comparadas a ébano, tocam as teclas de marfim do segundo. Sabe-se que, antigamente, muitos pianos tinham teclas brancas de marfim, sendo as teclas pretas comumente de ébano.

5 O termo aqui utilizado por Hughes é "raggy", aparentemente um neologismo ou gíria. A palavra parece oriunda de "rag", que significa andrajo, trapo. Daí nossa opção por "roto".

6 O original, neste ponto, repete o substantivo "thump", que poderia ser traduzido por "baque", "golpe" ou "pancada". No entanto, parece-nos que, mais importante do que buscar em português uma precisa sinonímia é reproduzir o som do onomatopaico vocábulo inglês, motivo por que optamos por "tum, tum, tum", reproduzindo o barulho dos pés do músico a bater no chão de modo a marcar o ritmo da canção. 
E foi cantando aquilo noite afora.

Lua e estrelas foram embora.

Ele parou e foi dormir no quarto,

No Miserável Blues ainda absorto.

Dormiu como uma pedra ou um homem que está morto.

O poema retrata a apresentação de um músico negro num bar na Lenox Avenue do Harlem. Um clima de pesar permeia os versos, repletos de palavras como "weary" e "sad", bem como alusões à morte. O blues é, para o músico e para o ouvinte, uma forma de consolo para as agruras da vida. Nesse sentido, o poema presta homenagem ao blues como música redentora, bem como à própria “alma do homem negro", da qual o blues provém.

Há certa identificação entre aquele que entoa o poema e aquele que entoa a canção. Em alguns momentos, o primeiro parece tomado pelos sentimentos que acometem ao último, quase como se quisesse unir-se a ele na cantoria. Segundo Steven Tracy, concorre para a união dos dois a sintaxe ambígua do poema, cujos versos iniciais podem referir-se tanto ao canto do pianista quanto ao dizer poético daquele que o observa (1988, p. 221).

Como primeiro problema tradutório, apresentou-se o título do poema, que é repetido em algumas passagens. A palavra "weary" significa algo como "abatido", "enfastiado" etc. Cremos que a expressão "miserável" se encaixa nesse mesmo campo semântico, sem, no entanto, perder certo coloquialismo que se espera de um cantor de blues. Optamos, ainda, por posicionar o termo "miserável" anteriormente a "blues", de modo a manter esse último vocábulo sempre no final dos versos, o que não só nos aproxima da tradição das canções americanas $^{7}$, mas também permite a homofonia com os versos do poema em que a palavra "blues" figura na posição derradeira ("sweet blues", "o blues" - versos 11, 14 e 16).

Outra palavra que chama a atenção no poema é o termo inglês "negro", que, na época, não era considerado pejorativo; pelo contrário, sua utilização por Hughes, seja em poemas, seja em ensaios, era frequente. Do mesmo modo, "negro”, em português, é expressão desprovida de qualquer conotação depreciativa,

\footnotetext{
7 A precedência do adjetivo em relação ao substantivo, evidentemente, constitui norma gramatical da língua inglesa. Em tese, não haveria problema algum em deslocarmos o adjetivo na tradução, pospondo-o ao substantivo, conforme a sistemática do português. No entanto, nossa decisão fundamentou-se na tradição do cancioneiro estadunidense, no qual são muito comuns títulos como "Cross Road Blues" e "Walkin’ Blues" (canções do bluesman Robert Johnson).
} 
motivo pelo qual a empregamos na tradução. No verso 15 , o poeta utilizou o sinônimo "black man", que, do mesmo modo, era tido como polido. Na falta de outra expressão em português que não incorra em depreciação, mantivemos o "negro" aí também.

No que tange a recursos sonoros, são empregados, além de outros, os da aliteração e assonância, já presentes no início do poema: "droning a drowsy". Na tradução ("zumbindo zonza"), procuramos, com a repetição consonantal da fricativa " $z$ ", sugerir a sonoridade de um "drone", isto é, um zumbido constante, como o das notas graves do piano a servir de base para o canto. A ênfase no som anasalado e esticado do "on", de "zonza", foi igualmente uma tentativa de manter a sensação de prolongamento do "droning".

Quanto às rimas, tivemos, de um modo geral, algum rigor. Atentemos para a tendência, comum nas canções em língua inglesa, de "valorização do acento secundário das proparoxítonas" (FALEIROS, 2006, p. 1-2). Trata-se de um deslocamento acentual, mediante o qual se rima a sílaba final de uma proparoxítona com a de uma oxítona. É o que ocorre nos versos 9/10 (key/melody). Tentamos atingir efeito análogo com a rima "ébano/piano".

No que diz respeito à cadência do poema, constata-se o uso de pés métricos diversificados. Dá-se alternância entre ritmos trocaicos e iâmbicos - os quais tentamos reproduzir em alguns momentos, como nos dois primeiros versos e no verso 31, por exemplo -, além de outros, menos demarcados e mais sincopados.

São dignos de nota os trechos em que o canto do pianista é transcrito (versos 19-22 e 25-30), com reprodução fiel do formato tradicional do blues. Aí, o poema se compõe em outro registro: o da fala do negro estadunidense da época, abrangendo seu sotaque e linguajar - trata-se do black english. Nessas passagens, valemo-nos de expressões da linguagem falada brasileira, como "num", "mundão" e "deixar ela de lado".

O poema como um todo possui dicção suave, o que nos levou a evitar rebuscamentos, privilegiando a simplicidade das construções. Trata-se de preservar o tom de naturalidade tão característico de Hughes, e que ele imprimiu ao poema mesmo nos momentos em que não se reproduz o canto do músico.

Ademais, buscamos, sempre que possível, manter a ordem das palavras em cada verso, como ocorreu, por exemplo, no verso 30 e no último do poema. É marcante o caráter imediato das assertivas "and I wish that I had died" e "he slept like a rock or a man that is dead". Quanto a esta última, fizemos questão de manter a colocação "um homem que está morto", em vez de algo como "um 
defunto" ou "um homem que morreu". Aqui, o poeta deu prevalência à condição perene de "estar morto", e não ao simples fato "morreu", exaustivo em si mesmo. De fato, o verbo de ação daria a noção de algo que se consuma no tempo de uma vez só, ao contrário da perenidade de quem se encontra morto, à qual se equipara a continuidade do ato de dormir (ainda mais em se tratando de um sono tão pesado como o que parece sugerir o poeta); assim, mantivemos o verbo de ligação "ser".

\section{Po’ Boy Blues ${ }^{8}$}

When I was home de

Sunshine seemed like gold.

When I was home de

Sunshine seemed like gold.

Since I come up North de

Whole damn world's turned cold.

I was a good boy,

Never done no wrong.

Yes, I was a good boy,

Never done no wrong,

But this world is weary

An' de road is hard an' long.

I fell in love with

A gal I thought was kind.

Fell in love with

A gal I thought was kind.

She made me lose ma money

An' almost lose ma mind.

Weary, weary,

Weary early in de morn.

8 Não temos ciência de nenhuma tradução desse poema para o português. 
Weary, weary,

Early, early in de morn.

I's so weary

I wish I'd never been born.

\section{Blues dum Pobre Garoto}

Lá em casa o sol

Era que nem ouro.

Lá em casa o sol

Era que nem ouro.

Desde que eu me vim embora,

Essa droga de mundo congelou.

Sempre fui um bom garoto,

Nunca fiz mal pra ninguém.

Sim, um bom garoto,

Nunca fiz mal pra ninguém.

Mas o mundo é miserável

E a estrada é dura e imensa.

Eu amei uma garota

Que eu achava boa à beça.

Eu amei uma garota

Que eu achava boa à beça.

Mas ela me torrou a grana

E quase também a cabeça.

Miserável, miserável,

Miserável logo cedo.

Miserável, miserável,

Nesse horário assim tão cedo.

Tô tão miserável que eu num

Queria nunca ter nascido. 
Vislumbram-se aqui os temas de migração, desilusão amorosa e desamparo na vida, por motivos socioeconômicos e emocionais. Se, em The Weary Blues, a reprodução do formato do blues se dava apenas em dois trechos, agora vemos um poema inteiramente estruturado desse modo. De fato, ele poderia perfeitamente ser musicado, e não é difícil imaginá-lo na voz de mestres do blues como Robert Johnson e Muddy Waters.

Justamente por ser um genuíno blues em sua inteireza, o poema compõese integralmente em black english. Na tradução, procuramos empregar expressões da linguagem falada, como "que nem", "droga", "tô" e "num" (em vez de "não").

Logo na primeira estrofe, deparamo-nos com um problema na palavra "North", quando o bluesman afirma que migrou do sul quente norte-americano para o norte gélido. Não só o fluxo migratório tradicional no Brasil é inverso, como também a questão climática. De fato, não faria sentido, por aqui, a associação norte - frio/ sul - quente. Assim, por uma questão de adequação ao público receptor da língua-cultura de chegada, decidimos por omitir a indicação geográfica, limitando-nos à questão da migração pouco auspiciosa. Cabe ao leitor interpretar o "congelamento do mundo" como uma hipérbole que encerra elementos de literalidade (o indivíduo de fato migrou para um local mais frio) ou como uma metáfora para as adversidades advindas da migração, ou ainda ambas as coisas.

A palavra "weary" se faz novamente presente. Por uma questão de coerência, tendo em vista a relevância desse vocábulo para Hughes, optamos por manter a mesma tradução usada no poema anterior: "miserável". Com a interação "miserável/horário" (versos 21/22), tentamos emular a relação algo paronomástica de "weary/early".

Ao contrário da tradução anterior, não fomos rigorosos com rimas, muitas das quais ficaram imperfeitas. Buscamos mais uma afinidade sonora - como em "ninguém/imensa" (segunda estrofe) - do que uma homofonia absoluta. Mas a maior flexibilidade rímica nos permitiu investir em outros aspectos do poema, como a precisão semântica e a manutenção da ordem dos termos nos versos.

No que diz respeito à cadência do poema, ele se caracteriza pelo uso reiterado de iambos e troqueus. Na tradução, usamos principalmente redondilhas maiores e menores, combinadas com alguns versos de 6 ou 8 sílabas poéticas. Tal combinação não nos parece problemática, tendo em vista a variação, já presente no original, da extensão dos versos. É que o blues, gênero musical dado a improvisos, não se atém ao quantum de notas predeterminado de uma partitura musical, comportando certa maleabilidade melódica e rítmica, o que sem dúvida foi assimilado por Hughes. 
A opção por redondilhas justifica-se pela analogia entre o blues, canção popular estadunidense, e as canções populares e folclóricas em língua portuguesa, em que os referidos metros são decerto os mais consagrados (particularmente a redondilha maior). Trata-se de raciocínio semelhante ao de Paulo Henriques Britto ao traduzir Emily Dickinson (2008), que do mesmo modo justificou sua tradução do metro de balada inglês por redondilhas, suscitando uma equivalência funcional.

\section{Conclusão}

Os blues poems espelham uma faceta de Hughes que, embora marcante, tem sido pouco explorada no âmbito da tradução brasileira, tendente a privilegiar os poemas mais politizados e conhecidos do autor. Buscamos transmitir, em nossas traduções, a espontaneidade e a musicalidade desse poeta que captou vivamente não só as agruras, mas também a cultura dos negros norte-americanos do início do século XX.

\section{Referências}

BRITTO, Paulo Henriques. "A Tradução para o Português do Metro de Balada Inglês". In: Revista Fragmentos, n. 34, jan-jun, 2008. pp. 25-33.

EMANUEL, James A. Langston Hughes. New York: Twayne Publishers, 1967.

FALEIROS, Álvaro. "Tradução e Canção no Ritmo do Trovador". In: Tradução em Revista, v. 3, 2006. pp. 1-10.

SOUZA, Elio Ferreira de. Poesia Negra das Américas - Solano Trindade e Langston Hughes. Tese de doutorado apresentada ao Centro de Artes e Comunicação da Universidade Federal de Pernambuco. Recife: 2006.

TRACY, Steven C. Langston Hughes and the Blues. Chicago: University of Illinois Press, 1988. 